\title{
Gastropleural fistula: a rare complication of a perforated gastric ulcer in a hiatus hernia
}

\author{
Samantha Ann Pellegrino (10 , Henry RE Drysdale, George Kalogeropoulos
}

Department of General Surgery, Barwon Health, Geelong, Victoria, Australia

\section{Correspondence to} Dr Samantha Ann Pellegrino; samantha.pellegrino8@gmail. com

Accepted 19 June 2021

\section{DESCRIPTION}

A woman in her late 60 s presented to hospital with a 1-day history of lethargy, confusion and worsening abdominal pain. This was on a background of several weeks of left-sided abdominal pain. There was no history of vomiting or haemoptysis. Her history included chronic renal impairment (baseline estimated glomerular filtration rate 16), and a known large hiatus hernia with Cameron erosions (identified on gastroscopy 6 months prior). She was experiencing gradual functional decline over the preceding months.

On arrival, she was critically unwell. She was hypothermic $\left(35^{\circ} \mathrm{C}\right)$, tachycardic $(140 / \mathrm{min})$, hypotensive $(70 / 45 \mathrm{~mm} \mathrm{Hg})$, hypoxic $\left(\mathrm{SpO}_{2} 94 \%\right.$ on high-flow oxygen), tachypnoeic (36/min) and had a Glasgow Coma Scale score of 12 . On examination, she was peripherally shut down and had decreased air entry to the entire left chest. Her abdomen was soft and non-tender. She received intravenous fluid resuscitation, was commenced on an adrenaline infusion and received broad-spectrum antibiotics/ antifungals. Bloods revealed haemoglobin $82 \mathrm{~g} / \mathrm{L}$, white cell count $27.5 \times 10^{9} / \mathrm{L}, \mathrm{C}$ reactive protein 213, $\mathrm{K}^{+} 7.6$ and eGFR 8. COVID-19 PCR later returned negative.

An X-ray of the chest showed complete white-out of left lung with significant mediastinal shift (figure 1). A CT of the chest/abdomen/pelvis showed a large left hydropneumothorax causing compressive mass effect on the heart and mediastinal structures and some free gas anterior to the aorta (figure 2).

She was intubated in the intensive care unit and commenced on noradrenaline and argipressin infusions. A left intercostal catheter (ICC) was

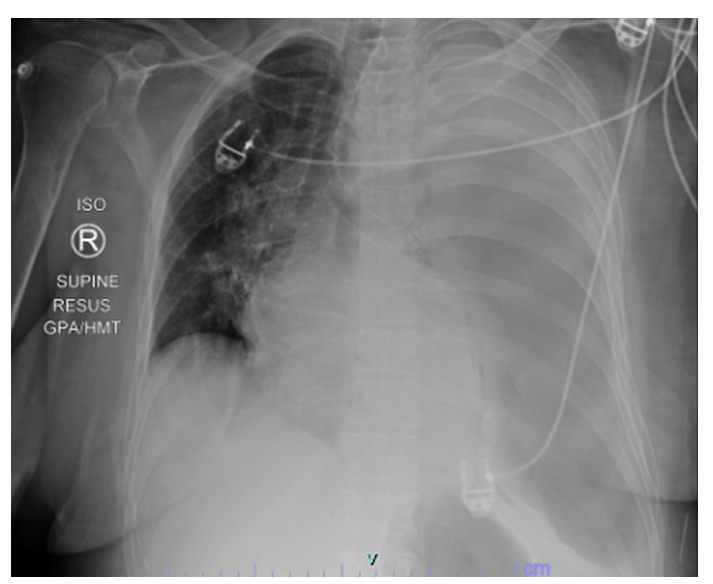

Figure 1 X-ray of the chest showing complete whiteout of the left lung with significant mediastinal shift.

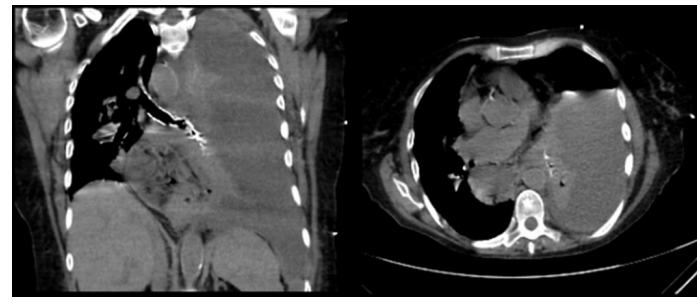

Figure 2 CT of the chest, abdomen and pelvis showing a large left hydropneumothorax causing compressive mass effect on the heart and mediastinal structures. Some free gas anterior to the aorta was suggestive of a gastropleural fistula due to a perforated hiatus hernia.

placed into the left pleural cavity with $1.5 \mathrm{~L}$ of gastric contents drained. A nasogastric tube was inserted. Her ionotropic requirement progressively increased, and she continued to have progressive renal impairment despite haemofiltration. A family meeting was held with the consensus being that proceeding with invasive and difficult surgical intervention was unlikely to result in a favourable outcome. Care was withdrawn and the patient passed away the same day.

A gastropleural fistula is an abnormal communication between the stomach and the pleural cavity. Gastropleural fistula due to intrathoracic gastric perforation in a hiatus hernia is exceptionally rare, with the incidence currently unknown. A limited number of cases dating back to the 1950s have been reported. ${ }^{1-4}$ All reported cases proved to be fatal, with our case being no exception.

The diagnosis is suspected when gastric fluid is obtained post insertion of an ICC. Pleural fluid analysis can be requested if there is any diagnostic uncertainty. While there are no hallmark signs of imaging, the presence of hydropneumothorax and pneumomediastinum are key diagnostic features,

\section{Learning points}

Gastropleural fistula due to intrathoracic gastric perforation in a hiatus hernia is exceptionally rare.

- The diagnosis is suspected when gastric fluid is obtained post insertion of an intercostal catheter along with radiological findings of hydropneumothorax and pneumomediastinum.

- The prognosis is poor, but surgical management involving a laparotomy and potentially a thoracotomy may be considered in selected patients. 
especially when interpreted in the appropriate clinical context. The prognosis is poor, but surgical management involving a laparotomy and potentially a thoracotomy has been described depending on the underlying aetiology. ${ }^{5-8}$ Partial or total gastrectomy may also be indicated. ${ }^{9}$

Our case highlights the presentation and diagnosis of this rare condition. Patients will usually present with sepsis and respiratory distress. Surgeons should consider this diagnosis in patients with a known hiatus hernia who present with a hydrothorax and gas in the pleural space on imaging. Prompt diagnosis is necessary, as without early surgical intervention mortality is high, as demonstrated by this case.

Contributors SAP and HD were responsible for: (1) Substantial contributions to the conception or design of the work, or the acquisition, analysis or interpretation of data. (2) Drafting the work or revising it critically for important intellectual content. (3) Final approval of the version published. (4) Agreement to be accountable for all aspects of the work in ensuring that questions related to the accuracy or integrity of any part of the work are appropriately investigated and resolved. GK was responsible for: (1) Substantial contributions to the conception or design of the work, or the acquisition, analysis or interpretation of data. (2) Revising the work critically for important intellectual content. (3) Final approval of the version published. (4) Agreement to be accountable for all aspects of the work in ensuring that questions related to the accuracy or integrity of any part of the work are appropriately investigated and resolved.

Funding The authors have not declared a specific grant for this research from any funding agency in the public, commercial or not-for-profit sectors.
Competing interests None declared.

Patient consent for publication Not required.

Provenance and peer review Not commissioned; externally peer reviewed.

\section{ORCID iD}

Samantha Ann Pellegrino http://orcid.org/0000-0003-4610-6858

\section{REFERENCES}

1 Pincus J, Zimmerman IA. Perforation of a hiatus hernia. N Y State J Med 1950;50:4568 , illust.

2 Blades B, Hall ER. The consequences of neglected hiatal hernias. Ann Surg 1956;143:822-32.

3 Markowitz AM, Herter FP. Gastro-pleural fistula as a complication of esophageal hiatal hernia. Ann Surg 1960;152:129-34.

4 Meredith HC, Seymour EQ, Vujic I. Hiatal hernia complicated by gastric ulceration and perforation. Gastrointest Radiol 1980;5:229-31.

5 O'Keefe PA, Goldstraw P. Gastropleural fistula following pulmonary resection. Thorax 1993;48:1278-9.

6 Biswas IH, Raghavan C, Sevcik L. Gastropleural fistula: an unusual cause of intractable postoperative nausea and vomiting. Anesth Analg 1996;83:186-8.

7 Bini A, Grazia M, Petrella F, et al. Spontaneous biliopneumothorax (thoracobilia) following gastropleural fistula due to stomach perforation by nasogastric tube. Ann Thorac Surg 2004;78:339-41.

8 Takeda S-I, Funaki S, Yumiba T, et al. Gastropleural fistula due to gastric perforation after lobectomy for lung cancer. Interact Cardiovasc Thorac Surg 2005;4:420-2.

9 Mehran A, Ukleja A, Szomstein S, et al. Laparoscopic partial gastrectomy for the treatment of gastropleural fistula. JSLS 2005;9:213-5.

Copyright 2021 BMJ Publishing Group. All rights reserved. For permission to reuse any of this content visit

https://www.bmj.com/company/products-services/rights-and-licensing/permissions/

BMJ Case Report Fellows may re-use this article for personal use and teaching without any further permission.

Become a Fellow of BMJ Case Reports today and you can:

- Submit as many cases as you like

- Enjoy fast sympathetic peer review and rapid publication of accepted articles

- Access all the published articles

- Re-use any of the published material for personal use and teaching without further permission

Customer Service

If you have any further queries about your subscription, please contact our customer services team on +44 (0) 2071111105 or via email at support@bmj.com.

Visit casereports.bmj.com for more articles like this and to become a Fellow 